\title{
Effect of phosphorus, sulphur and biofertilizer on productivity and soil fertility after harvest of moongbean grown on light textured soil of Kachchh
}

\section{A.H. SIPAI, J.S. JAT, B.S. RATHORE, KULDEEP SEVAK AND JITENDRASINGH JODHA}

MEMBERS OF RESEARCH FORUM:
Corresponding author :
A.H. SIPAI, Centre of Excellence for
Research on Organic Farming, S.D.
Agricultural University, Bhachau,
KACHCHH (GUJARAT) INDIA
Email: rrsbhachau@sdau.edu.in

Email: rrsbhachau@sdau.edu.in

Co-authors :

J.S. JAT, B.S. RATHORE, KULDEEP SEVAK AND JITENDRA SINGH JODHA, Centre of Excellence for Research on Organic Farming, S.D. Agricultural University, Bhachau, KACHCHH (GUJARAT) INDIA
Received : 27.06.2014; Revised : 15.10.2015; Accepted : 01.11.2015

\begin{abstract}
Summary
A field experiment consisted of 24 treatment combinations of three levels of phosphorus $(0$, $\left.20,40 \mathrm{~kg} \mathrm{ha}^{-1}\right)$ and three levels of sulphur $\left(0,20,40 \mathrm{~kg} \mathrm{ha}^{-1}\right)$ and two level of biofertilizer in form of Rhizobium inoculation (inoculated and uninoculated) was conducted with four consecutive years from 2007-08 to 2010-11 were tested with three replications effect of under factorial Randomized Block Design at Bhachau-Kachchh to study the effect of P, S and Rhizobium on productivity and fertility of soil after harvest of moongbean. The soil of the experiment field was sand loamy with alkaline in reaction, low in nitrogen, sulphur and zinc, medium in phosphorus and potassium. Application of $40 \mathrm{~kg} \mathrm{Pha}^{-1}$ and $40 \mathrm{~kg} \mathrm{~S} \mathrm{ha}^{-1}$ along with Rhizobium inoculation significantly increased the productivity of moongbean and improved the nutrient availability of soil at harvest of crop over the control. Maximum economic benefits of gross realization, net realization along with highest $\mathrm{BCR}$ of $6.73: 1$ under the treatment combination $\mathrm{P}_{2} \mathrm{~S}_{2} \mathrm{R}_{1}$.
\end{abstract}

Key words : Moongbean, Phosphorus, Sulphur, Rhizobium, Yield, Uptake, Availability of nutrient, Fertility of soil, Economics, Biofertilizer

How to cite this article : Sipai, A.H., Jat, J.S., Rathore, B.S., Sevak, Kuldeep and Jodha, Jitendra Singh (2015). Effect of phosphorus, sulphur and biofertilizer on productivity and soil fertility after harvest of moongbean grown on light textured soil of Kachchh. Asian J. Soil Sci., 10(2) : 228-236. 